\title{
Erratum to: The effect of juvenility and veneer thickness on bending strength of Douglas-fir laminated veneer lumber
}

Istie Rahayu $^{1}$ - Louis Denaud ${ }^{2}$ - Wayan Darmawan ${ }^{1}$ - Naresworo Nugroho ${ }^{1}$.

Remy Marchal ${ }^{3}$

Published online: 1 November 2016

(C) Indian Academy of Wood Science 2016

Erratum to: J Indian Acad Wood Sci (June 2016)

13(1):64-72

DOI:10.1007/s13196-016-0167-5

Mr. Julien Ruelle's name has been withdrawn as an author of this paper as his contributions are not a part of the final version of this article.

The online version of the original article can be found under doi:10.1007/s13196-016-0167-5.

Istie Rahayu

istiesr@ipb.ac.id

Louis Denaud

louis.DENAUD@ensam.eu

1 Department of Forest Products, Faculty of Forestry, Bogor Agricultural University (IPB), Bogor 16680, Indonesia

2 LABOMAP-Art et Metiers ParisTech-Centre de Cluny, Rue Porte de Paris, 71250 Cluny, France

3 CIRAD, 73 Rue Jean-François Breton, 34398 Montpellier Cedex 5, France 